\title{
ҮШ ҚҰРЫЛТАЙ, БІР БАЙЛАМ: ҚАЗАҚ ТІЛІНІН ЛАТЫННЕГІЗДІ ӘЛІПБИІ
}

\author{
Ergali ESBOSINOV
}

\begin{abstract}
Андатпа
1926 ж. Бакуде өткен атақты I-ші Баку Түркітану Құрылтайына сілтеме жасай отырып, қазіргі Түркия елінің алфавитінің нұсқасы мен арада ондаған жылдар салып барып қолға алынған Ортақ түрік алфавитіне шолу жасауға талпыныс жасалған. Ыстамбұлда Мармара Университеті жанындағы Түркітану институты үйымдастырған «Қазіргі түркі алфавиттері халықаралық симпозиумы - 1991» мен «Қазіргі түркі алфавиттері халықаральқ симпозиумы - 2018» туралы, осы жиынның тарихи шешімі туралы сөз болады. Мұндай келелі басқосу мен шешімнің түптамырында Түркия Республикасының сегізінші Президенті Тұрғыт Өзал мен Қазақстанның тұңғыш Президенті - Елбасы Н.Ә.Назарбаевтың 1990 жылғы кездесуі мұрындық болғандығы айтылады. Қорытынды ретінде Қазақстан Республикасының Президенті Қ.К.Тоқаевтың «Тіл мамандары жаңа әліпбиді жетілдіру керек» деген тапсырмасын орындау мақсатында А.Байтұрсынұлы атындағы Тіл білімі институты ұйымдастырған Республикалық дөңгелек үстел шешімі мен үндеуі туралы, көптен бері бейресми түрде қолданыста жүрген 32 қаріптік «жаңа қазақ» яки «Ортақ түрік алфавиті» туралы баяндалады.
\end{abstract}

Кілт Сөздер: Ортақ Түрік Алфавиті, Латын Негізді Жаңа Қазақ Әліпбиі, Түркі Елдері, Тұрғыт Өзал, Н.Ә.Назарбаев.

\section{ÜÇ KURULTAY BİR KARAR: KAZAK LATÍN ALFABESİ Özet}

1926 yılında Bakü'de gerçekleştirilen I. Türkoloji Kurultayından seneler sonra Türk Dünyasında Latin alfabesi konusu, 1991 ve 2018 yıllarında Marmara Üniversitesi Türkiyat Enstitüsündeki "Milletlerarası Çağdaş Türk Alfabeleri Sempozyumu"nda yeniden ele alınmıştır. Bilindiği üzere 1926 Bakü toplantısından sonra Türkiye, 1991 İstanbul toplantısından sonra da Azerbaycan Latin alfabesine geçiş yapmışlardır. Çalışmada Türkiye Cumhuriyeti'nin sekizinci Cumhurbaşkanı Turgut Özal ve Kazakistan'ın birinci Cumhurbaşkanı Nursultan Nazarbayev'in 1990 yılındaki görüş̧meleri ve bunun neticeleri de ayrıca tartışılacaktır. Latin alfabesine geçiş hazırlıkları yapan Kazakistan'ın mevcut Cumhurbaşkanı Tokayev, “dil uzmanlarının yeni Kazak Latin alfabesini geliştirmelerini beklemekteyiz" çağrısı yankı uyandırmış, bunun üzerine Almatı'da ülkenin önde gelen dil bilimci ve Türkologları bir araya gelip bir yuvarlak masa toplantısı gerçekleştirmişlerdir. $\mathrm{Bu}$ toplantının neticesinde Cumhurbaşkanlığı makamına sunulmak üzere temeli Türkiye'deki bilimsel toplantılarda atılan 32 harfli yeni Kazak alfabesi gündeme gelmiştir. Fonetik açıdan bir ses bir harf esasına dayalı bu alfabede Kazakçanın bütün seslerini karşılayacak işaretler yer almaktadır.

Anahtar Kelimeler: Ortak Türk Alfabesi, Yeni Kazak Latin Alfabesi, Türk Dünyas1, Turgut Özal, Nursultan Nazarbayev.

\footnotetext{
* Doç. Dr., Abay Kazak Milli Pedagoji Üniversitesi / Kazakistan, el-mek: ergaliesb@ mail.ru 


\section{THREE CONGRESSES, ONE DECISION: KAZAKH LATIN ALPHABET}

\section{Summary}

After the First Turkology Congress held in Baku in 1926, the subject of Latin alphabet in the Turkic World was reconsidered in the "International Symposium of Modern Turkish Alphabets" at the Institute of Turkic Studies of Marmara University in 1991 and 2018. As is known, in 1926 after meeting of Turkey, Baku, Azerbaijan in 1991 after the Istanbul meeting have made the transition to the Latin alphabet. President of Turkey Turgut Ozal, and President of Republic of Kazakhstan Nursultan Nazarbayev's first meeting in 1990, and consequently will also be discussed. The current President of Kazakhstan Tokayev, preparing for the transition to the Latin alphabet, called for is we expect the language experts to develop the new Kazakh Latin alphabet, and upon this, the leading linguists and Turkologists of the country came together and held a roundtable. Presidential authority to be presented on the basis of the result of this meeting, 32 letters thrown at scientific meetings in Turkey has reached a new Kazakh alphabet agenda. In phonetic terms, this sound is based on one letter and the rear signs that will meet all the sounds of Kazakh.

Key Words: Common Turkish Alphabet, New Kazakh Latin Alphabet, Turkish World, Turgut Özal, Nursultan Nazarbayev.

БІРІНШІ УӘЖ. Тарихи құжаттарға сілтеме: 1926 жыл, Азербайжан Кеңестік Социалисттік Республикасының астанасы Баку қаласы; түркі жұрттарының ана тілдеріне қатысты тарихтағы тұңғыш басқосуы ${ }^{1}$. Maқcam: дүйім түркіге ортақ, латын графикасы негізінде әмбебап алфавит түзу, бекіту, өндіріске енгізу. Құрылтай нәтижесі: латын графикасы негізінде түрік елдеріне ортақ алфавит қабылданды. Құрылтайға қатысушы елдер делегациясының мүшелері мақұлдап қол қойып, ресми түрде рәсімдеді; Қазақ елінінің атынынан Ахмет Байтұрсынұлықатысып, сол дәуір қазақ қоғамының нақты жағдайын ескеруге мәжбүр екендігін айта келе, түркі тілдері және қазақ тілінің сол кезең жағдайы туралы өзіндік құнды пікірлерін айтты. Ахаңның баяндамасы алғашқы құрылтайда тыңдалған ең мазмұнды да таңдаулы ғылыми баяндама ретінде тарих бетіне жазылды. Ал сол кезеңде алфавитке қатысты тарихи құжатты толық көлемде іске асыру бір ғана елдің еншісіне тиді, ол, - Түркия Республикасы еді. Тарихи дерек: Түркия Республикасының құрушысы, түрік халқының көшбасшысы Мұстафа Кемал Атаүрік, жаңа түрік алфавитін Баку Құрылтайы шешімі негізінде қабылдайтынын мәлімдеп арнайы шешім қабылдады, - ол сол дәуірдің қытымыр да алмағайып заманы - 1928 ж. 1ші қарашасы болатын.

Суретте Мұстафа Кемал Ататүріктің Баку Құрылтайы ұйғарымы бойынша мақұлдап, 1928 жылы өндіріске енгізген Түркия Республикасының латын негізді алфавиті (тарихи құжат) $)^{2}$.

${ }^{1}$ https://dalanews.kz/16201

2https://www.tarihakli.com/harf-devrimi/ 


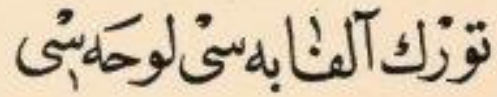

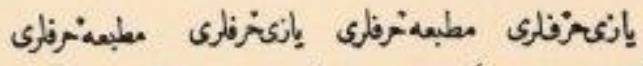

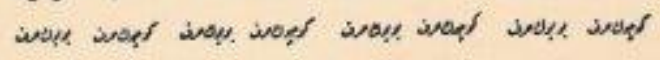

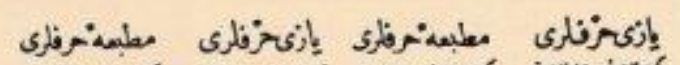

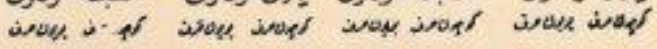
L $1 \mathscr{L} \ell$ S S $\mathscr{S}$ 。 $\mathrm{Mm} \mathscr{H}_{\mathrm{m}} \mathrm{S}$ S $\mathscr{S}$ $\mathbf{N} \mathbf{n} \mathscr{P}_{n} \mathbf{T} \mathbf{t} \mathscr{C} t$

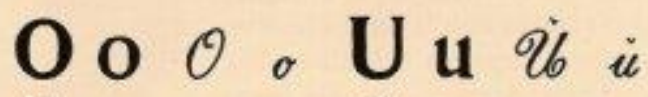
Ö $\ddot{0} \ddot{\theta} \quad \ddot{\sigma} \ddot{\mathbf{u}} \ddot{q} \ddot{u}$ $\mathbf{P} \mathbf{p} \mathscr{P} \boldsymbol{V} \mathbf{v}$ ขै $\operatorname{Rr} \mathscr{R} \bullet \mathbf{Y}$ y $y$ $\mathrm{Zz}$ 芕多

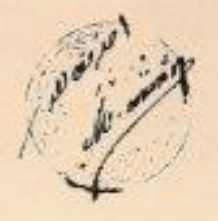

Нұрсұлтан Назарбаев, «Ұлы даланың жеті қыры»: Бүгінде төл тарихымызzа оң көзқ̧арас керек. Бірақ құандай да бір тарихи оқ̧ианы таңдамаль және конъюнктуральққ тұрвыдан гана сипаттаумен шектелуге болмайды. Ақ пен қара - бір-бірінен ажырамайтын ұвымдар. Бұлар өзара бірлескенде жеке адамдардың да, тұтас халықтардың да өміріне қайталанбас реңқк береді ${ }^{3}$.

ЕКІНШІ УӘЖ. 1991 жыл. Тәуелсіз Қазақстанның халықаралық аренадағы алғашқы қадамдары. Қазақстан Республикасының Президенті, Елбасы Нұрсұлтан Әбішұлы Назарбаевтің сындарлы да байсалды сыртқы саясатының алғашқы жемісті нәтижелері: түркі елдерінің бір-бірімен қайтадан және жаңаша жолыққан тарихи басқосуларының уақыты. Басқаша айтқанда, Елбасымыздың тікелей атсалысуы арқылы іске асқан Түркі әлемінің жаһандық аренаға жарқырап шыққан жұлдызды күндері. Бұл тарихи сәттердің негізі сонау Қазақ Кеңес Социалистік Республикасы Коммунистік Партиясының Бірінші Хатшысы, Қазақ ССР Министрлер Кеңесінің Төрағасы Н.Ә.Назарбаев пен Түркия Президенті Тұрғыт Өзалдың тарихи кездесуінде жатқандығын ${ }^{4}$ кейбір жағдайда есімізге ала бермейміз. 1991 жылдың басында, ол кезде Қазақ Кеңес Социалистік Республикасының Президенті болса да Н.Назарбаев, Мәскеудің келісім-рұқсатынсыз Түркия Президенті Тұрғыт Өзалға Қазақстанға ресми сапармен келуіне ұсыныс жасайды. Осылайша Н.Назарбаев, түркі елдерінің ішіндегі екі ірі мемлекетті «кездестіріп» тарихқа алтын әріппен жазылатын батыл да қайратты ісәрекетке барады. Бұл, сайып келгенде тоталитарлық режимге ашық түрде қарсы

${ }^{3}$ http://www.akorda.kz/kz/events/memleket-basshysynyn-uly-dalanyn-zheti-kyry-atty-makalasy ${ }^{4}$ https://e-history.kz/kz/contents/view/623 
шығудың өзіндің бір формасы еді. Өстіп, екі елдің президенттері жоғары деңгейде шартқа қол қойғаннан кейін үкімет басшылары, министрлер, ведомстволар және ірі ұлттық компаниялар жетекшілері арасында халықаралық келісімді орындау мақсатындағы іс-шаралар бірден қолға алынып нақты нәтижесін бере бастады. Ал сол кезеңдерде Кеңес Одағының өз шырмауына өзі шатасып жатқанымен әлі де ызғарлы да сүреңсіз уақыты екендігін айта бермейміз. Осы тарихи кездесуден кейін іле-шала Әзербайжан, Өзбекстан, Түркіменстан, Қырғызстан сияқты көршілес елдер Түркиямен екіжақты келесімдерге қол қойып жатты. Санаулы айлардың «ар жақ - бер жағында» «Еуразиялық мазмұн» мейлінше кең геосаяси мәнмен толыға түсті. Бұл табиғи үдеріс еді. Өйткені Президентіміз барлық бастамаларын қашан да біртұтас идеямен ұштастырудың хас шебері болатын. Ол кездері еуразиялық болашақ пен түркілік ынтымақтастық тоғысында жаңа бірлестік - ТМД-ны құру барынша өткір мәселе ретінде танылатын Сөйтіп, сонау 1990 ж. жасалған Келісімнің шапағаты, қазіргі тілмен айтқанда мультипликативтік әсері 1991 жылы қазанның 18-20 күндері Стамбұлдағы Мармара Университеті жанындағы Түркітану институты ұйымдастырған «Қазіргі түркі алфавиттері халықаралық симпозиумы» атауымен көрініс берді'.Танымал қазақ түркологтарының тілімен айтқанда бұл іс-шара, - сонау 1926 жылғы I-ші Баку Түркітану Құрылтайының 1991 жылы қайта жаңғырып қолға алынған және тәуелсіз түркі елдерінің басын қосқан ЕКІНШІ ТҮРКІТАНУ ҚҰРЫЛТАЙЫ десе де болатындай еді. Мақ̧сат: Баку Құрылтайында қолға алынған мәселені қайтадан күн тәртібіне қою. Тәуелсіз түркі елдеріне ортақ латын графикалы Ортақ түркі алфавитін түзу, өндіріске енгізу. Нәтижесі: 34 қаріптен тұратын Ортақтүркі алфавиті симпозиумға қатысушы тілші-мамандар тарапынан қабылданып түркі елдері үкіметтік органдарына ұсыныс ретінде ресми түрде хабарланды.Жиын соңы баспасөз үндеуі жарияланып қатысушы делегаттар қол қойды; Қазақстан делегациясы атынан түркітанушы-ғалым, академик, қоғам қайраткері Әбдуәли Қайдар мен түркітанушы-ғалым, академик Хұсайын Көбей, академик Кеңесбай Мұсаев сынды біртуар тұлғаларымыз болды.Осы басқосуды ұйымдастыруда профессор Ерден Қажыбек үлкен еңбек сіңірді.

Нұрсұлтан Назарбаев, «Ұлы даланың жеті қыры»: Біздің тарихымызда қ̧асіретті сәттер мен қ̧айдылы оқивалар, сұрапыл совыстар мен ққақтывыстар, әлеуметтік тұрвыдан қауіпті сынақттар мен саяси қугын-сүргіндер аз болмады. Мұны ұмытуга хақыммыз жоқ. Көпқырлы әрі ауқыымды тарихымызды дұрыс түсініп, құабылдай білуіміз керек ${ }^{7}$.

ҮШІНШІ УӘЖ: 2018 жыл. Стамбұл. Тарихи Баку Құрылтайы мен 1991 ж. Мармара Университетіндегі басқосудан кейінгі түркі елдерінің бетке ұстар ғалымдары мен қоғам қайраткерлері араға ондаған жыл салып тағы бір жиналды. Өкілі болып танылатын елдері мен жұрты есейді, бойы да ойы да өсті. Жан-жағын таныды, өзін танытты. Осындай табиғи уақыт сынының тезінде қазақ елі жеке дара қасақайып тұрды. Адымы кеңірек, тынысы молырақ екендігін бүкіл жаһанға паш етті. Бұл қазақ елінің басшысы, Елбасының ерен еңбегінің нәтижесі еді. Әлем мойындағандай Н.Ә.Назарбаевты дүйім түркі жұрты «біздің ақсақалымыз, үлкеніміз» деп ілтипат көрсетті, «Түркі елдерінің лидері» деп ресми емес «ат қойды»; саяси тұлғасының бұған бек лайық екендігін еліне, жұртына, тілі мен дініне қарамай мақтанышпен атап жатты. 2018 жылдың 21-ші қарашасында ҮШІНШІ ТҮРКІТАНУ ҚҰРЫЛТАЙЫ деп аталып кеткен Мармара Университеті жанындағы Түркітану институты ұйымдастырған «Қазіргі түркі алфавиттері халықаралық симпозиумы» атты Екінші халықаралық симпозиум өз

\footnotetext{
${ }^{5}$ https://kk.wikipedia.org/wiki/Тәуелсіз_Мемлекеттер_Достастығы

${ }^{6}$ Milletlerarası Çağdaş Türk Alfabeleri Sempozyumu. 18-20 Kasım, 1991. Marmara Üniversitesi Yayınları No: 509. Türkiyat Araştırmaları Enstitüsü Yayınları: 1. İstanbul, 1992.

${ }^{7}$ http://www.akorda.kz/kz/events/memleket-basshysynyn-uly-dalanyn-zheti-kyry-atty-makalasy
} 
жұмысын бастап кетті ${ }^{8}$. Мұнда 1991 ж. бірауыздан қабылданған 34 қаріпті Ортақ түркі алфавитін Қазақ еліне ұсынуды жөн деп тапты. Бұл жай ғана атау емес өз алдына жеке дара тарихи оқиға екендігін, бұған дәйекті де сындарлы уәждері бар екендігіне назар аударды. Оның ішінде;

- $\quad$ алфавит ондаған жылға созылған практикалық және теориялық тәжірибеден үздік шықты (бұған А.Байтұрсынұлы атындағы Тіл білімі инстиуты ғалымдарының ондаған жылдар бойы жүргізген тәжірибелері мен ғылыми еңбектері дәлел);

- $\quad$ алфавит жекелеген түркі елінің шекарасымен шектелмей дүние жүзіндегі барлық түркі елдерінің ана тілінде қолданыста болды, әр елдің ерекшелігіне орай «іздеутабу» жүйесімен қоса барлық электрондық бағдарламаларда қолданыста болды;

- заманауи технология қажет ететін барлық сыннан сүрінбей өтті;

- солай бола тұра бірде-бір, оның ішінде Қазақстан, түркі елінің ана тіліне, жазусызуына қағажу түсірмеді, дыбыстық-айтылымдық нормалары мен орфографиясына өзінше сіңісіп бейімделді;

- қалта телефонының бағдарламасынан бастап суперкомпьютердің графикалықесептік жүйеленуіне дейінгі аса күрделі ІІТ-технологияларға толығымен сай екендігін дәлелдеді.

Нұрсұлтан Назарбаев, «Ұлы даланың жеті қыры»: Біз басқа халықтардың рөлін төмендетіп, өзіміздің ұлылывылмызды көрсетейін деп отырганымыз жоқ. Ең бастысы, біз нақты вылыми деректерге сүйене отырып, жаһандық тарихтагы өз рөлімізді байыппен әрі дұрыс пайымдауга тиіспіз ${ }^{9}$ :

Интернет кеңістігін ондаған жылдар бойы «иемденіп жүрген» ОРТАҚ ТYРІК (ҚАЗАҚ) АЛФАВИТІ:

\begin{tabular}{|c|c|c|c|c|}
\hline 1. A a & 8. $\mathbf{F ~ f ~}$ & 15. K k & 22. Ö ӧ & 29. $\ddot{\mathbf{U}} \ddot{\mathbf{u}}$ \\
\hline 2. & 9. $\mathbf{G ~ g}$ & 16. Q q & 23. P p & 30. V v \\
\hline B b & 10. $\breve{\mathbf{G}} \breve{\mathbf{g}}$ & 17. L I & 24. R r & 31. W w \\
\hline $\mathrm{C} \mathbf{c}$ & 11. $\mathbf{H ~ h}$ & 18. M m & 25. S s & 32. $\mathbf{X} \times$ \\
\hline Ç ç & $12 . \mathbf{I}_{\mathbf{I}}$ & 19. N n & 26. Ş ş & 33. Y y \\
\hline D d & 13. $\mathbf{I} \mathbf{~ i ~}$ & 20. $\mathbf{D} \mathbf{~}$ & 27. $\mathbf{T ~ t}$ & 34. Z z \\
\hline 7. $\mathbf{E} \mathbf{e}$ & 14. J j & $21.0 \mathrm{o}$ & 28. $\mathbf{U} \mathbf{u}$ & \\
\hline
\end{tabular}

БАЙЛАМ: 2019 ж. 6-шы қарашасында Алматыдағы «Достық үйінің» дөңгелек залында еліміздің іргелі ЖОО өкілдерімен қоса Халықаралық «Қазақ тілі» қоғамының Президенті, ҚР ҰҒА академигі, проф., др. Өмірзақ Айтбаев, Ш.Шаяхметов атындағы «Тіл-Қазына» ұлттық ғылыми-практикалық орталығының Бас директоры Әлібек Асқар, Абай атындағы Қазақ ұлттық педагогикалық университетінің ректоры, проф., др. Тахир Балықбаев, Назарбаев Университеті Қазақ тілі және түркітану кафедрасының мегерушісі, профессор Юлай Шамилоғлы, Ахмет Байтұрсынұлы атындағы Тіл білімі институтынан профессор Әлімхан Жүнісбек, аталмыш институт директоры ф.ғ.д. Е.З.Қажыбек және басқа да танымал қазқ тілі мамандары мен түркологтар бас қосып, келелі жиын мен мазмұнды басқосудың нәтижесі ретінде баспасөз хабарламасын таратты: «ҚАЗАҚ ТІЛІНІН ЖАНА ӘЛІПБИІ: Тіл мамандарының ортақ тұжырымы» атты ғылымипрактикалық дөңгелек үстел БАСПАСӨЗ ПАРАҒЫ: Мемлекет басшысы Қ.Тоқаевтың «Тіл мамандары жаңа әліпбиді жетілдіру керек» деген тапсырмасын орындау мақсатында

${ }^{8}$ https://tilalemi.kz/article/1829-.html

${ }^{9}$ http://www.akorda.kz/kz/events/memleket-basshysynyn-uly-dalanyn-zheti-kyry-atty-makalasy. 
- Қазақстан Республикасы Президентінің жанындағы Қоғамдық сананы жаңғырту бағдарламасын іске асыру жөніндегі ұлттық комиссияныңҚазақ тілін латын графикасына көшіру жөніндегіжұмыс тобы

- Халықаралық Түркі академиясы

- Қазақстан халқы Ассамблеясы

- Халықаралық «Қазақ тілі» қоғамы

- Назарбаев университеті

- ҚР БҒМ ҒК Ахмет Байтұрсынұлы атындағы Тіл білімі институты

- Абай атындағы Қазақ ұлттық педагогикалық университеті

- Әл-Фараби атындағы Қазақ ұлттық университеті

- Лев Гумилев атындағы Еуразия ұлттық университеті

- Қожа Ахмет Ясауи атындағы Халықаралық қазақ-түрік университеті

- Халықаралық түріктану орталығы

- Абылай хан атындағы Қазақ халықаралық қатынастар және әлем тілдері университеті

- Тараз мемлекеттік педагогикалық университеті

- Еуразия ғылыми-зерттеу институты

- Қазақ ұлттық қыздар педагогикалық университеті

- Мемлекеттік тілді дамыту институты

және республиканың басқа жоғары оқу орындары менғылыми-зерттеу институттарының тіл мамандары биылғы жылдың 6 қарашасында, сәрсенбі күні,«ҚАЗАҚ ТІЛІНІН ЖАНА ӘЛІПБИІ: Тіл мамандарының ортақ тұжырымы» атты ғылыми-практикалық дөңгелек үстелге қатысып, жасалған ғылыми баяндамалар мен жан-жақты егжей-тегжейлі талқылау нәтижесінде ортақ шешім қабылдады.

Тіл мамандары 1991 жылы ұсынған Ортақ түркі әліпбиіне, 1992-1995 жылдары халықаралық конференциялардың қарарларына сәйкес, 2006-2015 жылдар аралығындаҚР БҒМ ҒК Ахмет Байтұрсынұлы атындағы Тіл білімі институты зерттеулері нәтижесі бойынша, 2012 жылғы 1 желтоқсанда түркі тілдес мемлекеттердің «Türk Keneşi» халықаралық ынтымақтастық ұйымыныңұсынымына сай, 2015-2016 жылдары Халықаралық Түркі академиясының ғылыми зерделеуі мен соның қорытындысы ретінде ұсынылған қазақ тілінің латын графикасы негізіндегі ұлттық әліпбиінің нұсқасына және Қазақстан Республикасы Президентінің жанындағы Қоғамдық сананы жаңғырту бағдарламасын іске асыру жөніндегі ұлттық комиссияның Қазақ тілін латын графикасына көшіру жөніндегі жұмыс тобының 2017 жылы тамыз айында бекіткен әліпбиі негізінде - «ҚАЗАҚ ТІЛІНІҢ ЖАНА ӘЛІПБИІ: Тіл мамандарының ортақ тұжырымы» атты ғылыми-практикалық дөңгелек үстелдің қатысушылары бірауыздан төмендегі Қазақ тілінің латыннегізді әліпбиін қабылдады ${ }^{10}$ :

\begin{tabular}{|l|l|l|l|}
\hline A a & $\breve{G} \breve{g}$ & L l & S s \\
\hline$\ddot{\text { a }} \mathbf{a}$ & H h & M m & Ş s s \\
\hline B b & İ i & N n & T t \\
\hline Ç c & I l & D $\mathbf{~}$ & U u \\
\hline
\end{tabular}

\footnotetext{
${ }^{10} \mathrm{https} / / /$ egemen.kz/article/213005-zhanha-alipbige-qatysty-til-mamandarynynh-ortaq-tudgyrymy-talqylandy
} 


\begin{tabular}{|c|c|c|c|}
\hline D d & $\mathbf{Y} \mathbf{y}$ & O o & $\ddot{\mathbf{U}} \ddot{\mathbf{u}}$ \\
\hline $\mathbf{E} \mathbf{e}$ & $\mathbf{J} \mathbf{j}$ & 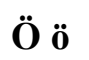 & $\mathbf{V}_{\mathbf{v}}$ \\
\hline F f & K k & $\mathbf{P} \mathbf{p}$ & $\mathbf{W}_{\mathbf{w}}$ \\
\hline G g & $\mathbf{Q q}$ & $\mathbf{R} \mathbf{r}$ & $\mathbf{Z}_{\mathbf{z}}$ \\
\hline
\end{tabular}

\section{Ескерту1:}

1. [цйдыбысы $\boldsymbol{y}$ әрпімен беріледі.

2. [i] дыбысының [b] сыңары ұқсас өтаңбасымен беріледі.

3. $\quad$ ә әрпімен қазақтың төл дауыссыз дыбысы таңбаланады: taw, sawap.

\section{Ескерту 2:}

Халықаралық практикаға сәйкес, кейбір кірме дыбыстар төл дыбыстарды таңбалайтын әріптермен беріледі. Бұл мәселе арнайы ережемен реттеледі -

4. [i] әрпімен төл сөздерде [i] дыбысы (ini, kim, til, din)және кірме сөздерде [и] дыбысы (ministr, internet[министр, интернет]) таңбаланады.

5. [u] әрпімен төл сөздердегі [ұ] дыбысын да (ult, tul, tur, Nur-Sultan),кірме сөздерде кездесетін дауысты [у] дыбысын да (universitet, prokuratura) таңбалаймыз.

P.S. Қазақтың этнографиясы мен фолкльорінде айшықты да шырайлы теңеу мен афоризмдер аз емес. Сол сөздердің бірі байлам ${ }^{11}$. Қазақ атамыз ұзын-сонар, ит жығыс дау-дамайдан жалығып, тоқ етерін айтқысы келгенде, яки естігі келгенде «байлам, байлам» деп атой салған. Мұны естіген атқамінерлер қалың жұрттың қалауынан қаймығып «байламға» келген. Өстіп күрделі өрілген баудың шешуін тапқан, «тоқ етер» сөзін айтқан. Мұны қара халық куанса да күйінсе де оңды қабылдап «дауымыз байламын тапты» деп жыраққа шабарман аттандырған. 21-ші ғасырға аяқ басқан шағымызда жаңа қарпімізді сомдап-түгендеп бір «байламға» байлап жер-жаһанға шабарман аттандырармыз ба?!

\footnotetext{
${ }^{11}$ Байлам1. бауды буатын бумасы; баулық; біріктіріліп байланған зат, бума. 2. шешім, тоқтам. Байлам жасады - шешімге келді, тоқтам жасады. 99 бет.
} 


\section{Сілтеме жасалған дереккөздер:}

Milletlerarası Çağdaş Türk Alfabeleri Sempozyumu. 18-20 Kasım, 1991. Marmara Üniversitesi Yayınları No: 509. Türkiyat Araştırmaları Enstitüsü Yayınları: 1. İstanbul, 1992.

Қазақ тілінің түсіндірме сөздігі. Жалпы ред. басқарған Т. Жанұзақов. Алматы: Дайк пресс - 2008.

https://dalanews.kz/16201

https://www.tarihakli.com/harf-devrimi/ makalasy

http://www.akorda.kz/kz/events/memleket-basshysynyn-uly-dalanyn-zheti-kyry-atty-

https://e-history.kz/kz/contents/view/623

https://kk.wikipedia.org/wiki/Тәуелсіз_Мемлекеттер_Достастығы

http://www.akorda.kz/kz/events/memleket-basshysynyn-uly-dalanyn-zheti-kyry-attymakalasy

https://tilalemi.kz/article/1829-.html

http://www.akorda.kz/kz/events/memleket-basshysynyn-uly-dalanyn-zheti-kyry-attymakalasy

https://egemen.kz/article/213005-zhanha-alipbige-qatysty-til-mamandarynynhortaqtudgyrymy-talqylandy 